\title{
Crossing Success in Abies nordmanniana Following Artificial Pollination With a Pollen Mixture of A. nordmanniana and A. alba
}

\author{
By O. K. Hansen ${ }^{*}$ and U. B. Nielsen \\ Danish Centre for Forest, Landscape and Planning, University of Copenhagen, \\ Hørsholm Kongevej 11, 2970 Hørsholm, Denmark
}

(Received $15^{\text {th }}$ November 2006)

\begin{abstract}
Controlled crossings were conducted with three Abies nordmanniana genotypes acting as mothers and a pollen mixture of three Abies nordmanniana genotypes and one Abies alba genotype acting as potential fathers. The aim was to investigate hybridization success under circumstances where pollen from both species are present, which is a potential risk in Danish clonal seed orchards of Abies nordmanniana. The number of seeds sired by each father was determined through SSRs and compared to the expected numbers based on the pollen mixture composition. All three mother genotypes of Abies nordmanniana had more progenies with the Abies alba as father (hybrids) than expected, based on proportions in the pollen mix. This indicates that no reproductive barriers between the two species exist, and that seed orchard managers should take precautions to avoid hybrids in seed crops. Furthermore, the experiments revealed quite different siring success of the three Abies nordmanniana genotypes, depending on which clone was the mother. Abies nordmanniana seed orchards should therefore not be established in the vicinity of Abies alba in the flowering age, and if a few-clone set up is chosen, the mating interaction should be investigated beforehand through pollen mix experiments.
\end{abstract}

Key words: Abies nordmanniana, Abies alba, hybridization, pollen mixture, seed orchard contamination.

\section{Introduction}

Interspecific hybridization is an important issue in many research disciplines such as taxonomy, ecology and conservation genetics (RHYMER and SIMBERLOFF, 1996; ARNOLD, 1997; RIESEBERG, 1997). In forest tree breeding, interspecific hybridization has traditionally been seen as a means to obtain desirable genotypes which could be useful in forestry (e.g. KLAEHN and WINIESKI, 1962; WRIGHT, 1976; FowLER, 1978), and several successful examples exist for conifers (FowLER, 1978). However, in other forest tree improvement cases interspecific hybridization is highly undesirable. The present study deals with such a situation.

Abies nordmanniana (Stev.) Spach, originating from the Caucasian region in Southern Russia, Eastern Georgia and North-eastern Turkey, and Abies alba Mill., originally distributed in central and southern Europe (LIU, 1971), are widely used exotic conifers in Denmark. A. nordmanniana is used mainly for Christmas tree and greenery production on farmland and, to a lesser extent,

\footnotetext{
*) Correspondence and reprints: Tel. +45 353316 47, Fax: +45 35 3315 17, E-mail: okh@life.ku.dk.
}

on forest sites while $A$. alba is used for timber production in forests. The use of $A$. nordmanniana for Christmas tree production in Denmark has increased considerably in the last 10-15 years peaking around 2004 with 10-11 mill. trees sold per year (Kaj Østergaard pers. comm.). The industry is mainly based on imported material (DiTlEVSEN and NiELSEN, 1997), but seeds for Christmas tree production have been harvested in Danish stands of $A$. Nordmanniana for years as well. Furthermore, a Danish breeding programme for $A$. nordmanniana was started in the early 1990 s with the aim of producing improved planting material for the production of Christmas trees (NIELSEN, 1994). Seed orchards made of progeny tested clones were established in this programme; they are expected to produce seeds in commercial amounts in a few years (NIELSEN, 2000).

Danish Christmas tree growers have been aware of hybridization between the two species for a long time, based on phenotypic observations (JACOBSEN, 1988). The hybrids are considered less suitable as Christmas trees, having tendencies to give 'open' trees because of vigorous growth, flatter foliage structure, poorer post harvest needle retention and earlier bud break (JACOBSEN, 1988; NiELSEN and ChASTAGNER, 2005). The latter gives increased risk of frost damage which is unacceptable in Christmas trees. Artificial hybridization experiments have confirmed this ability of A. nordmanniana and A. alba to hybridize (KORMUTAK, 1997). Thus, A. alba is present in forest stands at variable distances from the orchards, and at the same time it is well known that some species show long distance transportation of pollen and contribute substantially to background pollination in seed orchards (PAKKANEN et al., 2000; PARANTAINEN and PulKKInEN, 2003). Consequently a closer investigation of hybridization between the two species seemed important for A. nordmanniana seed orchard management.

Normally, hybridization among species is investigated through the use of controlled crossings with one species used as mother and the other as father (pollen donor). These settings, however, are quite far from the reality the seed producing trees experience in the seed orchards. In A. nordmanniana orchards, the air is expected to contain mostly pollen of this species and perhaps some A. alba pollen from surrounding forests. Therefore, it seems to be more relevant to look at how easily hybridization takes place when pollens from both species are present than to carry out pure interspecific crossings. Our protocol was inspired by LINDGREN and 
YAZDANI (1988) and others (e.g. NAKAMURA and WHEELER, 1992a), who used pollen mixtures with known proportions of pollen from different genotypes and afterwards studied the resulting progeny. However, besides mixing pollen from different genotypes of the same species, we also included pollen from another hybridizing species. The composition of the offspring will allow us to estimate the rate of hybridization between $A$. nordmanniana and A. alba under circumstances which are likely to be found in the operational seed orchards of A. nordmanniana.

\section{Material and Methods}

In general, in order to be sure of adequate sample sizes (constrained by limited resources) only a few genotypes were selected for the study. Also in the preparation of the pollen mix (see below), statistical considerations supported by power analysis led to the chosen composition with $50 \%$ of $A$. alba pollen, even though this is not likely to be found in the pollen cloud of an $A$. nordmanniana seed orchard.

\section{Collection, extraction and storage of pollen}

Branches with male strobili were collected from three A. nordmanniana ortets (selected plus-trees included in the breeding programme) in the approved Danish seed stands F.526 and F.527 and a second generation stand originating from F.525 (located respectively in Tversted Dune forest, departments 599 and 623 and Lilleheden dept. 852c). The branches were collected on May 13, 2003 , and pollen extraction started the day after by placing twigs with male strobili in terylene bags at $25^{\circ}$ $\mathrm{C}$ and letting them shed pollen through a combined filter and funnel into glass ampoules. Shedding normally takes place within few days. A. alba pollen originated from a tree standing in the Arboretum in Hørsholm (Accession no. 1959.4023 - originating from Delnice in Croatia) and was treated in the same way as the A. nordmanniana pollen. After extraction the pollen lots were freeze dried in order to improve storage and homogenize pollen moisture content. The pollen was then stored at minus $20^{\circ} \mathrm{C}$ until May 2004, when the pollen mixtures were prepared by the use of a balance.

Pollen viability was tested using a modified Brewbaker and Kwack's solution (BREWBAKER and KWACK, 1963; WEBBER and PAINTER, 1996). After 48 hours at $26^{\circ} \mathrm{C}$ the numbers of swollen and germinating pollen grains were counted and the percentage of viable pollen was calculated for each potential father. Furthermore, the size of the pollen grains of the different sources was measured under a microscope with 400x magnification. Pollen testing and measurements were carried out a year after pollination, on the same pollen lots as those used in pollination.

\section{Seed orchard and pollination procedure}

The pollinations were conducted in the clonal seed orchard (CSO) FP259, established in 1993-94 in Silkeborg State forest District (Jutland). It consists of clones selected in the approved Danish seed stands F.526 and F.527 (1st generation from directly imported seeds) and in the seed stand Lilleheden dept. $852 \mathrm{c}$ ( $2^{\text {nd }}$ generation). All the clones have been selected for foliage appearance. The possibility of having hybrids in the $2^{\text {nd }}$ generation material (Lilleheden) is therefore highly unlikely since hybrids have flatter foliage structure with an unattractive appearance.

Female flowers were isolated on 27-29 th $^{\text {April }} 2004$, using terylene bags and water repellent cotton wool. Flowers were isolated on clones of three different genotypes (one ramet per clone), chosen for their high number of female flowers. Two genotypes originated from Lilleheden dept. 852c and one from F.526 (Tversted). Ten terylene bags, typically isolating two or three female flowers, were put on each of the three clones. Female flowers were pollinated twice on May 4 and 6 with a pollen mixture. The mixture was made of $50 \%$ of A. alba pollen and $15.7 \%$ of pollen from each of the three A. nordmanniana plus-trees - based on weight. One single glass ampoule containing the pollen mixture was used on each of the pollination days meaning that all three mother clones were exposed to exactly the same pollen mixture. The bags were removed on June 6 and the cones were harvested on September 28. The cones collected from each clone were pooled together and the three cone crops were kept separate. Then, the seeds were extracted manually, dried, cleaned and kept at $5{ }^{\circ} \mathrm{C}$ until stratification and germination.

\section{DNA extraction}

Seed stratification started in the beginning of February 2005. The seeds from each lot were wrapped in wet paper, placed in plastic bags and kept refrigerated at $5{ }^{\circ}$ C. Normally $A$. nordmanniana seeds need $3-6$ weeks of stratification before they start to germinate (NYHOLM, 1986), but our seeds did not start to germinate before the $9^{\text {th }}$ week. The germinating seeds where then removed successively from the refrigerator and kept for ten days at $15^{\circ} \mathrm{C}$, allowing the embryos to elongate faster. The elongated embryos were cut out of the seeds and DNA was extracted using the DNeasy Plant Mini Kit from QIAGEN (Germany). Mother and father clones were characterized using DNA extracted from needles.

\section{Parent and progeny genotyping}

The three mother clones, the four pollen donors and all viable progeny in the three seed lots were genotyped with microsatellites (SSRs) recently developed in A. nordmanniana (HANsen et al., 2005). On the whole, 225 seeds were genotyped, including 67,80 and 78 seeds from the three mother clones C26, C91 and C94 respectively. Among the five SSRs available, two were sufficient (NFH3 and NFH15) to identify the pollen donors of the progenies. The microsatellites were multiplexed using the QIAGEN ${ }^{\circledR}$ Multiplex kit (catalogue no. 206143). PCR conditions followed the standard multiplex PCR protocol given in the instructions of the QIAGEN multiplex Kit and amplifications were carried out in a Perkin Elmer thermal cycler (model 9700). Fragment sizes of the amplified labelled SSRs were determined using the CEQ 2000XL Fragment analysis system from Beckman Coulter. 


\section{Statistics}

For each mother tree a chi-square goodness of fit test was performed (SNEDECOR and COCHRAN, 1980), to compare actual and expected contributions of the pollen donors $(d f=3)$. In order to test for differences in viable seed production ability between $A$. nordmanniana and A. alba pollen, the seeds sired by the three clones of A. nordmanniana were pooled and a chi-square test $(d f=1)$ was performed on the number of progenies obtained from each species. This analysis was carried out at two levels: i) for each mother tree separately and ii) globally after pooling the data obtained in the three mother trees. Differences in pollen viability and size were tested using a standard ANOVA.

\section{Results}

The genotypes of the potential parents are shown in Table 1. The exceptionally high power of discrimination of the applied markers was emphasized by the fact that only one parent (A. nordmanniana C94) was homozygous - and only for one of the two microsatellites. Only alleles which exist in the potential parents were found in the seeds analysed, giving strong evidence that no pollen-contamination had occurred, and confirming that female flowers had been isolated in proper time.

The results of the paternity analysis are indicated in Table 2 and illustrated in Figure 1. The A. alba pollen contributor in each seed lot has produced more than $50 \%$ of the offspring, even though its pollen only consti-

Table 1. - Parental genotypes given in base pairs for each allele in the two microsatellites and pollen size and viability of the four potential fathers. Pollen sizes and viability percentages followed by different letters are significantly different ( $5 \%$ level).

\begin{tabular}{|c|c|c|c|c|c|c|c|c|c|}
\hline & \multirow[t]{2}{*}{ Origin } & \multicolumn{2}{|c|}{ Microsatellite: NFH1 } & \multicolumn{2}{|c|}{ NFH3 } & \multicolumn{3}{|c|}{ Pollen size / mm } & \multirow{2}{*}{$\begin{array}{c}\text { Pollen viability } \\
n \mathrm{n}=443-485\end{array}$} \\
\hline & & Allele 1 & Allele2 & Allele 1 & Allele2 & & $\mathrm{n}=35$ & & \\
\hline Fathers & & & & & & Mean & Std & $\mathrm{CV}$ & Mean \\
\hline A.alba Delnice & Croatia & 107 & 122 & 105 & 120 & $0.0959^{\mathrm{a}}$ & 0.0039 & 0.04 & $58.6 \%^{\mathrm{ab}}$ \\
\hline A.nord. C19 & F.526 & 103 & 105 & 127 & 161 & $0.0964^{\mathrm{a}}$ & 0.0049 & 0.05 & $48.6 \%{ }^{\mathrm{a}}$ \\
\hline A.nord. C46 & F. 527 & 103 & 113 & 125 & 137 & $0.0975^{\mathrm{a}}$ & 0.0050 & 0.05 & $62.3 \%{ }^{\mathrm{b}}$ \\
\hline A.nord. C81 & F.525 & 99 & 105 & 118 & 124 & $0.1041^{\mathrm{b}}$ & 0.0057 & 0.05 & $78.9 \%{ }^{c}$ \\
\hline \multicolumn{10}{|l|}{ Mothers } \\
\hline A.nord. C26 & F. 526 & 101 & 113 & 120 & 140 & & & & \\
\hline A.nord. C91 & F. 525 & 103 & 105 & 118 & 131 & & & & \\
\hline A.nord. C94 & F. 525 & 103 & 105 & 125 & 125 & & & & \\
\hline
\end{tabular}

Table 2. - Numbers of seeds sired by each father clone in three clones of Abies nordmanniana (C26, C91 and C94). (a) Expected proportion of seeds from each pollen donor. (b) Observed number and percentage of seeds from each pollen donor in each of the three seed lots. (c) Observed and expected number of seeds - pooled results from all three seed lots observed also given in percentage. (d) Expected number of seeds for each pollen donor, adjusted for differences in pollen size. (e) Expected number of seeds for each pollen donor, adjusted for differences in pollen viability. (f) Expected number of seeds for each pollen donor, adjusted for differences in both pollen size and viability.

\begin{tabular}{|c|c|c|c|c|c|c|c|}
\hline & & \multicolumn{4}{|c|}{ Fathers } & \multirow[b]{2}{*}{ Total } & \multirow[b]{3}{*}{ (a) } \\
\hline & & A.alba - Delnice & A.nord. C19 & A.nord. $\mathrm{C} 46$ & A.nord. C81 & & \\
\hline Seedlot & Proportion in pollenmix & $1 / 2=50 \%$ & $1 / 6=16.7 \%$ & $1 / 6=16.7 \%$ & $1 / 6=16.7 \%$ & $1=100 \%$ & \\
\hline SLC26 & $\#$ seeds / seeds in $\%$ & $39(58 \%)$ & $4(6 \%)$ & $6(9 \%)$ & $18(27 \%)$ & 67 & (b) \\
\hline SLC91 & \# seeds / seeds in $\%$ & $54(67 \%)$ & $8(10 \%)$ & $11(14 \%)$ & $7(9 \%)$ & 80 & (b) \\
\hline SLC94 & $\#$ seeds / seeds in $\%$ & $46(59 \%)$ & $14(18 \%)$ & $17(22 \%)$ & $1(1 \%)$ & 78 & (b) \\
\hline Overall & $\#$ seeds/ seeds in $\%$ & $139(62 \%)$ & $26(12 \%)$ & $34(15 \%)$ & $26(11 \%)$ & 225 & (c) \\
\hline & $\begin{array}{l}\text { Expected number } \\
\text { (pollen weight) }\end{array}$ & 112.5 & 37.5 & 37.5 & 37.5 & 225 & (c) \\
\hline $\begin{array}{r}\text { Expec } \\
\text { (nu) }\end{array}$ & $\begin{array}{l}\text { cted number/ percentage } \\
\text { mber of pollen grains) }\end{array}$ & $118.3(53 \%)$ & $38.6(17 \%)$ & $37.4(17 \%)$ & $30.6(13 \%)$ & 225 & (d) \\
\hline Expec & $\begin{array}{l}\text { ted number/ percentage } \\
\text { (pollen viability) }\end{array}$ & $108.2(48 \%)$ & $29.9(13 \%)$ & $38.4(17 \%)$ & $48.6(22 \%)$ & 225 & (e) \\
\hline $\begin{array}{l}\text { Expec } \\
\text { (no. of }\end{array}$ & $\begin{array}{l}\text { ted number/ percentage } \\
\text { pollen grains + viability) }\end{array}$ & $115.0(51 \%)$ & $31.2(14 \%)$ & $38.7(17 \%)$ & $40.1(18 \%)$ & 225 & (f) \\
\hline
\end{tabular}



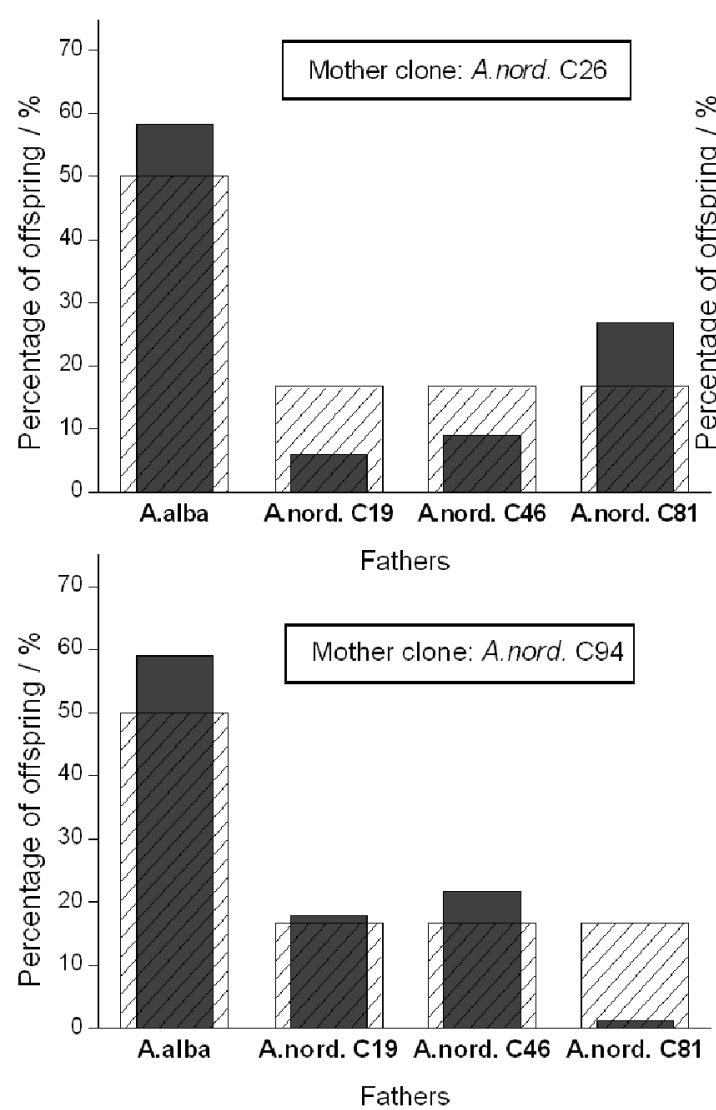

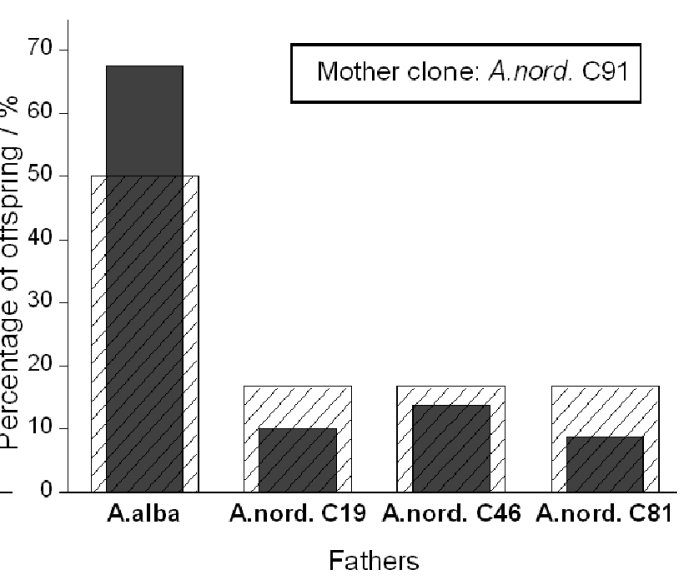

Observed no. of offspring Expected no. of offspring

Figure 1. - Observed and expected numbers of seeds sired by different male parents after pollination of three clones of Abies nordmanniana (C26, C91 and C94). Expected numbers are equal to the relative proportions (weight:weight) of the fathers in the pollen mixture.

tuted $50 \%$ of the pollen mixture. What is further striking is the difference in paternal success among the A. nordmanniana pollen contributors, when comparing the three seed lots. Thus A. nordmanniana C81 only sired one single seed in seed lot SLC94 (instead of the 13 seeds expected), while it sired 18 seeds in seed lot SLC26, where the expected number was 11. In all three seed lots, the number of progenies per father significantly differed from that expected on the basis of the pollen mixture composition (chi-square goodness of fit test with $d f=3$, SLC26: $\mathrm{p}=0.007$; SLC91: $\mathrm{p}=0.015$ and SLC94: $\mathrm{p}=0.003$ ). The causes of these significant deviations vary from one seed lot to another. In SLC26 the biggest contribution to the chi-square test statistic comes from the higher than expected number of $A$. nordmanniana C81 progenies and the fewer than expected progenies from $A$. nordmanniana $\mathrm{C} 19$, while the biggest chisquare contribution in SLC91 is due to the high number of $A$. alba progenies (67.5\% against the expected $50 \%$ ). For SLC94 the significant deviation is mostly due to the exceptionally low number of progenies with A. nordmanniana C81 as father.

Pooling the offspring from the three $A$. nordmanniana donors and comparing them to the number of $A$. alba progenies showed that despite a higher than expected number $(>50 \%)$ of $A$. alba progenies in the three seed lots, this higher proportion was only significant in SLC91. $(p=0.179, p=0.002, p=0.113$ in SLC26, SLC91 and SLC94 respectively). Nevertheless, the overall chi- square goodness of fit test, comparing the total of 139 A. alba progenies in the three seed lots with the 86 having a A. nordmanniana father, was highly significant $(\mathrm{p}<0.001)$.

Pollen sizes as well as pollen viability of the four potential fathers were measured to test for significant differences and, if any, to be able to adjust the number of expected progenies from each father. Significantly different pollen sizes would imply that e.g. a father with small pollen grains would have relatively more pollen grains in the mixture than indicated by its proportion in weight. Likewise, fathers with significant more viable pollen would have relatively more offspring than indicated by weight proportions in the pollen mixture. In fact, one father (A. nordmanniana C81) had significantly larger pollen than the others (Table 1). An adjusted number of expected progenies based on the number of pollen grains of each father in the mixture was calculated assuming that pollen grains were spherical (Table $2-$ row $d$ ). This adjustment resulted in a reduction of the gap between the observed and expected numbers of progenies, but the difference was still significant $(p=0.005)$. The same adjustment used for the data in each cross (results not shown) only led to minor changes in the chi-square tests, and did not change the overall conclusions. Pollen viability also showed a significant variation among potential fathers. A. nordmanniana C81 had the highest pollen viability $(79 \%$ - Table 1$)$ while A. nordmanniana $\mathrm{C} 19$ had the lowest with $49 \%$ 
viable pollen. As for pollen size, an adjusted number of expected progenies based on pollen viability of each father in the mixture was calculated (Table 2 - row e). Again, this did not change the overall conclusions much, even though the pollen viability had quite a different impact on expected number of progenies compared to pollen size. For example, A. nordmanniana C81 had only an expectation of $13 \%$ offspring due to large pollen size, but an expectation of $22 \%$ offspring when pollen viability was considered alone. A combined adjusted number, based on both number of pollen grains and viability was also calculated, giving intermediate expectation values compared to the two former adjustments (Table 2 - row f). In all three cases of adjustment, the expected proportion of $A$. alba progenies was close to $50 \%$ - the weight proportion in the pollen mix which was the starting point.

\section{Discussion}

Overall our study had two key findings: 1) The success of $A$. nordmanniana pollen parents with A. nordmanniana females showed considerable variation depending on the male/female combination and 2) A higher mating success of the A. alba father (interspecific cross) compared to the $A$. nordmanniana fathers (intraspecific cross).

\section{Mating success variation across different \\ A. nordmanniana male/female combinations}

A strong interaction of pollen donors with seed parents are of high practical interest to the Danish $A$. nordmanniana breeding programme. In the production of Christmas trees, using an exotic conifer in short rotation, concern about genetic diversity is not so relevant. A straight forward strategy could therefore be to establish clonal seed orchards with a very limited number of highly selected clones in order to maximize genetic gain (HANSEN and KJÆR, 2006). However, if setting up orchards with e.g. only 3-4 clones, it would be highly desirable to know whether these clones can actually mate and produce viable seeds.

A strong interaction among pollen donors and seed parents was found by APsit et al. (1989) in crosses with two-parent pollen mixes in a Douglas fir seed orchard. They called this interaction male-female complementarity. Later this male-female complementarity was confirmed in additional studies of Douglas fir (NAKAMURA and WHEELER, 1992ab), but otherwise the literature does not report about this phenomenon in other conifers. A commonly mentioned reason for differential male reproductive success is pollen competition (e.g. AronEn et al., 2002), which can be influenced by a whole range of factors involved in the striving of pollen grains to fertilize the same ovules (STEINER and GrEgORIUS, 1999). This includes pollen viability which we tested, although the assay was conducted one year after pollination. The significant differences in pollen viability found among the four pollen donors, however, can not explain the interaction among the three $A$. nordmanniana and neither the higher mating success of the A. alba donor, since the latter only had the third-highest pollen viability.
While pollen competition is a prezygotic event, acting on the haploid male gametophytic level, another factor, often regarded as more important, is postzygotic embryo abortion (MORAN and GRIFFIN, 1985; NAKAMURA and WHEELER, 1992a). This selection process is possible since polyembryony is common in gymnosperm species but only one embryo in each ovule normally develops to maturity (DoGRA, 1967). In conifers this means that several genetically identical archegonia within the same ovule can be sired by pollen from different fathers (HEDRICK et al., 1999). It is quite plausible that polyembryony can be the cause of the strong interaction we observed, simply because the embryos in some mother trees may be more prone to abortion when fertilized by certain pollen donors. However, the approach we used gives no possibility to test this hypothesis, and only few empirical studies have done so. Through controlled pollinations in a seed orchard O'CONNEL and RITLAND (2005) tested whether polyembryony can decrease seed abortion or the proportion of selfed seedlings in Thuja plicata. They could not find an increase in seed set attributable to polyembryony, but did actually observe that trees receiving high ratios of self-pollen produced fewer selfed seedlings than expected, which suggest embryo competition.

Finally, one might imagine that the mating success interaction among pollen donors and seed parents in our study could be caused by differences in relatedness among the tested individuals, either at provenance or family level. At provenance level, barriers to crossing between provenances could potentially give interaction. This seems, however, highly unlikely, as our three A. nordmanniana pollen donors in the pollen mix came from three different seed sources (Lilleheden, F.526 and F.527) and the three seed parents trees originate from Lilleheden (C91 and C94) and F.526 (C26). Looking at the results (Table 2), it is seen that when the pollen donor and the seed parent were from the same seed source they had the lowest mating success in all three cross combinations. Hypothetically this could be caused by relatedness at family level, where close relationship among pollen donor and seed parent may cause inbreeding and by that lower mating success. Again, this seems not plausible; all three seed sources originally had thousands of trees, and the chance that we have included close relatives in all three of them is minimal.

\section{Higher mating success of the interspecific cross}

The ability of Abies species to hybridize has not been as extensively investigated as in other genera of Pinaceae such as Pinus or Picea (CRITChFIELD, 1988). A few studies were made in the 1960's (KLAEHN and Winieski, 1962; MERGEN et al., 1964) which gave the impression that there is little difficulty in hybridizing fir species and that no reproductive barriers to crossing between individuals of different geographic regions exist (MERGEN et al., 1964). Later studies in the 1980's by HaWley and Dehayes (1985), St. Clair and CRITChField (1988), CRITCHFIELD (1988) and KoRMUTAK (1997) modified this view, and e.g. indicated a strong reproductive isolation between the North American members of the genus and their European counterparts (CRITCHFIELD, 
1988; KoRMutak, 1997). HaWley and Dehayes (1985) studied crossability among seven North American firs, where crossabillity was estimated by average viable seed yields of intertaxon relative to intrataxon crosses. They found that most crosses among species from the same section (here Balsameae) yielded a percentage of viable seed which was not significantly different from that of intrataxon crosses, and therefore appear to be fully crossable. Most intersectional crossing, however, yielded a low percentage of viable seed and accordingly reflected restricted crossabillity (HAWLEY and DEHAYES, 1985). This pattern with high crossability within groups but difficult or impossible crosses between groups was also supported by CRITCHFIELD (1988) who studied hybridization of California firs.

Our study with $A$. nordmanniana and $A$. alba, both in the Abies section (LIU, 1971), is not fully comparable with the above cited studies. We used pollen mix containing several genotypes and two species, in contrast to the earlier reported crosses with no possibility for pollen competition etc. Nevertheless, our results, where the intertaxon combination of seed parent and pollen donor had higher competitiveness in relation to mating success, strongly suggest full crossability between $A$. nordmanniana and $A$. alba, even though only one $A$. alba genotype was tested. This general trend in all three crosses could hypothetically be explained by different effects of storage on the pollen viability; say the A. alba pollen had lost more viability during the year from the crossing experiment until the pollen viability was measured. We have, though, no reason to believe so. Also, a few other reports about higher intertaxon success in Abies exist. KORMUTAK (1992) found higher efficiency of interspecific hybridization between $A$. concolor and A. grandis compared to intrataxon crosses, resulting in a $170 \%$ degree of crossability. Likewise, HAWLEY and DEHAYES (1985) observed that intrasectional crosses involving Abies fraseri pollen and female parents of Abies balsamea var. phanerolepis almost always produced more viable seed than the intrataxon controls.

In relation to management of seed sources of $A$. nordmanniana the present study makes it possible to draw the following conclusions: 1) The earlier reported crossing compatibility between A. nordmanniana and A. alba has been verified, and extended to conditions where pollens of both species are present. 2) Although only one specimen of $A$. alba has been tested, our results are in line with other studies which have reported high within section crossability in Abies species and 3) There seems to be large interaction among pollen donors and seed parents of A. nordmanniana, which may have importance in relation to the establishment of few-clone seed orchards.

A. alba generally has earlier vegetative bud break than A. nordmanniana material of central Georgian origin (LøFTING, 1973). However, this difference in timing might not hold true for reproductive buds, and a substantial overlap in flowering period is a potential risk. Seed source managers could have hoped, that reproductive barriers would make interspecific crosses relatively less frequent than intraspecific crosses, but our results do not support that hope. On the contrary, the present study shows that an $A$. alba tree can be just as competitive during pollination (and even more so). Therefore, managers have to take the risk seriously, e.g. by removing A. alba trees in the flowering age standing in the vicinity of the seed source, or by establishment of clonal seed orchards on agricultural lands, away from forested areas.

The issue about hybridization between A. alba and A. nordmanniana, together with the strong interaction in siring success observed among fathers of A. nordmanniana, should be further explored in future crossing experiments.

\section{Acknowledgments}

We thank ERIK D. KJÆR for helpful comments and inspiring discussions in relation to the pollination work. We also thank an anonymous reviewer for constructive suggestions to the manuscript, the Arboretum in Hørsholm for free use of the collection, KRISTIAN STOUSGAARD JACOBSEN for help with seed handling and JERRY W. LEVERENZ for valuable corrections of the language. Finally we are grateful to "Foreningen Plan-Danmark" who supported the presented work financially.

\section{References}

Apsit, V. J., R. R. NAKAmura and N. C. Wheeler (1989): Differential Male Reproductive Success in Douglas-Fir. Theor. Appl. Genet. 77, 681-684.

ARNOLD, M. L. (1997): Natural Hybridization and Evolution, Oxford University Press, New York, New York.

Aronen, T., T. Nikkanen, A. Harju, H. Tiimonen and H. HAGgMaN (2002): Pollen competition and seed-siring success in Picea abies, Theor.Appl.Genet. 104, 638-642.

BREWBAKER, J. L. and B. H. KWACK (1963): Essential Role of Calcium Ion in Pollen Germination and Pollen Tube Growth, Am. J. Bot. 50, 859-865.

CRITCHFIELD, W. B. (1988): Hybridization of the California Firs. Forest Science 34, 139-151.

Ditlevsen, B. and U. B. Nielsen (1997): Den fremtidige frøforsyning af nordmannsgran, Skoven 453-457.

DoGRA, P. D. (1967): Seed sterility and disturbances in embryogeny in conifers with particular reference to seed testing and tree breeding in Pinaceae, Stud. For. Suec. 45, 5-97.

Fowler, D. P. (1978): Population improvement and hybridization, Unasylva 30, 21-26.

Hansen, O. K., G. G. Vendramin, F. Sebastiani and K. J. Edwards (2005): Development of microsatellite markers in Abies nordmanniana (Stev.) Spach and cross-species amplification in the Abies genus, Mol. Ecol. Notes 5, 784-787.

Hansen, O. K. and E. D. KJÆR (2006): Paternity analysis with microsatellites in a Danish Abies nordmanniana clonal seed orchard reveals dysfunctions. Canadian Journal of Forest Research 36, 1054-1058.

HaWley, G. J. and D. H. Dehayes (1985): Hybridization Among Several North-American Firs. 1. Crossability. Canadian Journal of Forest Research 15, 42-49.

Hedrick, P. W., O. SAVOlainen and K. KarkKainen (1999): Factors influencing the extent of inbreeding depression: an example from Scots pine. Heredity 82, 441-450.

JACOBSEN, F. (1988): Juletræer og Klippegrønt in H. A. HENRIKSEN (Ed.), Skoven og dens dyrkning, Dansk Skovforening, Nyt Nordisk forlag Arnold Busck, Copenhagen, pp. 607-636. 
KLAEHN, F. U. and J. A. WINIESKI (1962): Interspecific hybridization in the genus Abies, Silvae. Genet. 11, 130-142.

KORMUTAK, A. (1992): Artificial hybridization between the white fir (Abies concolor Gord. et Glend./Lindl.) and grand fir (Abies grandis Dougl./Lindl.). Lesnictvi Forestry (Prague) 38, 759-769.

KoRMUTAK, A. (1997): Cytological aspects of interspecific hybridization in true firs (Abies species). In: BoRZAN, Z., Schlarbaum, S. E. (eds.), Cytogenetic studies of forest trees and shrub species Brijuni, Croatia, 8-11 September 1993. 303-310.

LiNDGREN, D. and R. YAZDANI (1988): Paternal contributions following artificial pollination in Pinus sylvestris (L.), Scand J Forest Res 3, 299-304.

LIU, T.-S. (1971): A Monograph of the genus Abies, Department of forestry, National Taiwan University, Taipei, Taiwan.

LøFTING, E. C. L. (1973): A survey of the present state of Abies nordmanniana in Denmark, Forstlige Forsoegsvaesen i Danmark 33, 303-326.

Mergen, F., J. Burley and B. A. Simpson (1964): Artificial hybridization in Abies. Der Zuchter 34, 242-251.

Moran, G. F. and A. R. GRIFFIN (1985): Non-random contribution of pollen in polycrosses of Pinus radiata D. Don, Silvae. Genet. 34, 117-121.

NAKamura, R. R. and N. C. Wheeler (1992a): Pollen Competition and Paternal Success in Douglas-Fir, Evolution 46, 846-851.

NAKAMura R. R. and N. C. WheELER (1992b): Self-Fertility Variation and Paternal Success Through Outcrossing in Douglas-Fir. Theor. Appl. Genet. 83, 851-854.

Nielsen, U. B. (1994): Breeding noble fir (Abies procera Rehder) and nordmann fir (Abies nordmanniana (Stev.) Spach) for Christmas trees and greenery in Denmark. Proceedings - Nordic group for tree breeding, Edinburgh, Scotland, 1993, 118-127. Forestry Commission, Edinburgh, Scotland.
NiELSEN, U. B. (2000): Forædling af nordmannsgran og nobilis: Status og muligheder., Pyntegrøntserien 15, $1-54$.

Nielsen, U. B. and G. A. Chastagner (2005): Variation in postharvest quality among Nordmann fir provenances, Hortscience 40, 553-557.

NyHOLM, I. (1986): Håndbog i frøbehandling, Dansk Planteskoleejerforening.

O'Connell, L. M. and K. Ritland (2005): Post-pollination mechanisms promoting outcrossing in a self-fertile conifer, Thuja plicata (Cupressaceae). Canadian Journal of Botany 83, 335-342.

Pakkanen, A., T. Nikkanen and P. Pulkkinen (2000): Annual variation in pollen contamination and outcrossing in a Picea abies seed orchard, Scand. J. Forest. Res. 15, 399-404.

Parantainen, A. and P. PulkKinen (2003): Flowering and airborne pollen occurrence in a Pinus sylvestris seed orchard consisting of northern clones, Scand. J. Forest. Res. 18, 111-117.

Rhymer, J. M. and D. SimberlofF (1996): Extinction by hybridization and introgression, Annual Review of Ecology and Systematics 27, 83-109.

RIESEBERG L. H. (1997): Hybrid origins of plant species, Annual Review of Ecology and Systematics 28, 359-389.

SNEDECOR, G. W. and W. G. Cochran (1980): Statistical Methods, The Iowa State Univ. Press, Ames, Iowa.

StCLAIR, J. B. and W. B. CRITChFIELD (1988): Hybridization of A Rocky-Mountain Fir (Abies Concolor) and A Mexican Fir (Abies Religiosa). Canadian Journal of Forest Research 18, 640-643.

Steiner, W. and H. R. Gregorius (1999): Incompatibility and pollen competition in Alnus glutinosa: Evidence from pollination experiments, Genetica 105, 259-271.

WEBBER, J. E. and R. A. PAINTER (1996): Douglas-fir Pollen Management Manual. Work. Pap. 02/1996. Res. Br., B. C. Min. For.

WRIGHT, J. W. (1976): Introduction to forest genetics, Academic Press, London, UK.

\title{
Spontaneous Hybridization between Pinus sylvestris L. and $P$. mugo Turra in Slovakia
}

\author{
By A. KormutaK ${ }^{1), *)}$, B. Demankova ${ }^{1)}$ and D. GömörY ${ }^{2)}$
}

(Received $28^{\text {th }}$ November 2006)

\begin{abstract}
Molecular evidence for spontaneous hybridization between Pinus sylvestris L. and P. mugo Turra in the putative hybrid swarm populations of the species in Slo-

\footnotetext{
1) Institute of Plant Genetics and Biotechnology, Slovak Academy of Sciences, Akademicka 2, P.O.Box 39A, SK-950 07 Nitra, Slovak Republic.

2) Technical University in Zvolen, Faculty of Forestry, T. G. Masaryka 24, SK-960 53 Zvolen, Slovak Republic.
}

*) Corresponding author: E-mail: nrgrkorm@savba.sk
\end{abstract}

vakia was provided based on PCR-RFLP analysis of the cpDNA trnV-trn $\mathrm{H}$ region. Species-specific restriction profiles generated by Hinf I digests of the cpDNA products reliably identified $P$. sylvestris and $P$. mugo haplotypes of the embryos from open pollination. Simultaneous analysis of the respective cpDNA region in megagametophytes and embryos of individual seeds along with needles of a given maternal tree has enabled to score either the $P$. sylvestris or $P$. mugo haplotypes in the embryos illustrating hybridization patterns between the two species. Data obtained in this way indicate a 